\title{
Investigation of the components nature and concentration influence on carbon dioxide equilibrium in the system $\mathrm{CaCl}_{2}-$ $\mathrm{Na}_{2} \mathrm{CO}_{3}-\mathrm{NaOH}-\mathrm{H}_{2} \mathrm{O}$ by potentiometric titration
}

\author{
Bulat Gilfanov ${ }^{1, *}$, Andrey Chichirov ${ }^{1}$, and Natalia Chichirova ${ }^{1}$ \\ ${ }^{1}$ Kazan state power engineering university, Russia, 420066 Krasnoselskaya, 51, Kazan
}

\begin{abstract}
The modern thermal power plants equipment requires strict deposits control on the surfaces. Such deposits are formed from impurities entering the cycle with water, the amount of which has significantly increased at modern powerful thermal power plants. At the modern level of the coolant water treatment, it is possible to exclude most of the impurities responsible for salt deposition. Analysis of various types of the sediments has shown that carbonate deposits are an integral part of them. Modern research methods (potentiometric titration in combination with methods of mathematical modelling) for carbonate, silicate, phosphate water systems have shown the existence of phase-unstable states leading to salt deposition during the coolant circulation. In this article, the carbonate system $\mathrm{CaCl}_{2}-\mathrm{Na}_{2} \mathrm{CO}_{3}-\mathrm{NaOH}-\mathrm{H}_{2} \mathrm{O}$ was studied by potentiometric titration with a glass indicator electrode. The influence of the components nature $\left(\mathrm{Li}_{2} \mathrm{CO}_{3}, \mathrm{Na}_{2} \mathrm{CO}_{3}, \mathrm{Ca}_{2} \mathrm{CO}_{3}, \mathrm{LiOH}, \mathrm{NaOH}, \mathrm{KOH}, \mathrm{CaCl}_{2}, \mathrm{MgCl}_{2}\right)$ and the conditions for the existence of phase-unstable systems with varying concentrations of these components were studied. It is known that organic phosphonates are effective inhibitors of deposits in the carbonate system. In this paper, the action of two compounds of the specified class is considered. The concentration limits of their inhibitory action have been determined.
\end{abstract}

\section{Introduction}

In the production of thermal and electrical energy at modern thermal power plants, water treatment systems are used, which constantly produce phase instability. Such systems include (1) water systems at intermediate stages of water treatment, in particular, lime-coagulated or clarified water after preliminary treatment, (2) cooling water in the station's recirculating cooling system, (3) water coolant in coupled heating networks, (4) boiler water. All these systems are characterized by the presence of a stabilized (metastable) solid phase, mainly calcium carbonate, capable of forming a crystalline calcite phase under certain conditions. The crystallization process is undesirable, since it can lead to the appearance of dense deposits on the heat transfer surfaces. Roughly, the instability of such systems is characterizing by the value of $\Delta \mathrm{TA}$ - the change in the total alkalinity of water over time (hours, days). There is currently no method for the quantitative determination of stabilized calcium carbonate in water systems of thermal power plants. Development of a technique for potentiometric analysis of carbonate-alkaline solutions is presented in the source [2].

\section{Method}

One of the sources of precipitation on the thermal power plants equipment, as follows from the literature data [2], are phase-unstable solutions that appear at different stages of the coolant movement, which is explained by a change in the components concentration, the alkalinity of the medium, temperature, pressure and other factors. The authors proposed a method for detecting such systems and analyzing their characteristics based on a combination of experimental results of $\mathrm{pH}$-metric (potentiometric) with the mathematical modeling methods. The possibility of using this method to identify such systems and analyze the effectiveness of sediment inhibitors was considered.

The objectives of the scientific paper:

- Reproduction of $\mathrm{pH}$ spectra for the $\mathrm{CaCl}_{2}-\mathrm{Na}_{2} \mathrm{CO}_{3}-$ $\mathrm{NaOH}-\mathrm{H}_{2} \mathrm{O}$ system according to data in which a phaseunstable solution is realizing;

- Obtaining the characteristics of $\mathrm{pH}$ spectra for this system;

- The possibility of using the phosphonate "ACTIFOS" as an inhibitor of sedimentation (solution stabilizer);

- Obtaining data on the influence of the nature of the alkali metal cation $(\mathrm{Li}+-\mathrm{Na}+-\mathrm{K}+)$ on the $\mathrm{pH}$ spectra in the system under consideration.

\footnotetext{
* Corresponding author: $\underline{b}$ _gilfanov@,bk.ru
} 


\section{Results and discussion}

The experiment was carried out according to the method described in the article. All initial solutions were prepared on the basis of distillate and dry chemically pure substances. 10 minutes after preparation of the solution, potentiometric titration of the solutions with 0.1 $\mathrm{N} \mathrm{HCl}$ solution was carried out. Titration was performed in a potentiometric cell closed from the atmosphere with a working glass electrode and a silver chloride reference electrode. During the titration, the solution was stirred with a magnetic stirrer. The glass electrode was calibrated against standard buffer solutions. The results obtained were presented in the form of dependences in the coordinates of $\mathrm{pH}-\Delta \mathrm{pH} / \Delta \mathrm{V} ; \mathrm{pH}-\mathrm{VHCl} ; \mathrm{VHCl}, \mathrm{ml}-$ $\Delta \mathrm{pH} / \Delta \mathrm{V}$. Determining the equivalence point from a differential curve is much more accurate than from a simple $\mathrm{pH}-\mathrm{V}$ relationship. For each sample of solutions, a volumetric titration of $0.1 \mathrm{~N}$ was performed $\mathrm{HCl}$ solution with indicators methyl orange and phenolphthalein [3].

The results of $\mathrm{pH}-$ metric and volumetric titrations, mathematically processed to obtain graphical dependences and $\mathrm{pH}$-spectra for one solution, are shown in Figures 1 and 2.

The results of $\mathrm{pH}$-metric titration and calculations of solutions are presented, sample $\mathrm{CaCl} 2(0.2 \mathrm{mM})$, $\mathrm{Na} 2 \mathrm{CO} 3(0.5 \mathrm{mM}), \mathrm{NaOH}(0.8 \mathrm{mM})$

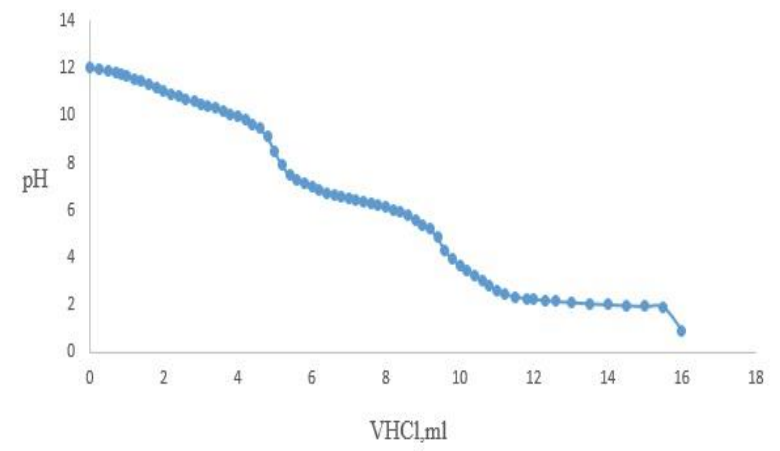

Fig. 1. Potentiometric titration curve for solution (composition ms: $\left.\mathrm{CaCl}_{2}-\mathrm{Li}_{2} \mathrm{CO}_{3}-\mathrm{LIOH}-\mathrm{H}_{2} \mathrm{O}\right)$.

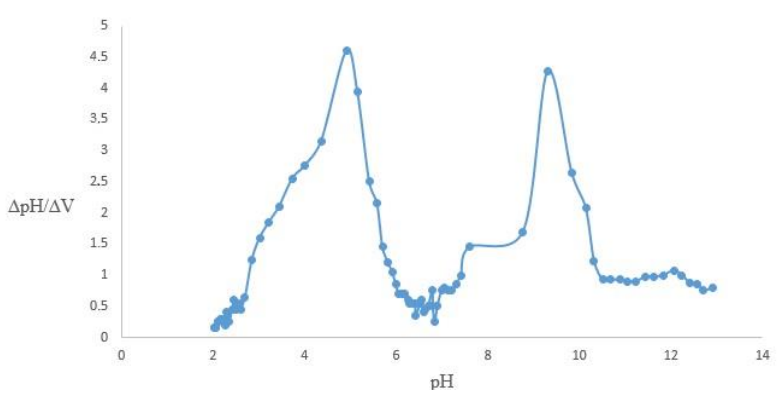

Fig. 2. pH spectrum for solution (composition of $\mathrm{ms}: \mathrm{CaCl}_{2}$ $\left.(2 \mathrm{mM})-\mathrm{Na}_{2} \mathrm{CO}_{3}(10 \mathrm{mM})-\mathrm{NaOH}(20 \mathrm{mM})\right)$.

The characteristics of the $\mathrm{pH}$ spectrum in the system under consideration for the sample according to the experimental results are shown in Table 1 [3].
Table 1. Characteristics of the $\mathrm{pH}$ spectrum in the considered system for the sample according to the experimental results.

\begin{tabular}{|c|c|c|c|c|}
\hline \multirow[t]{2}{*}{ Peak } & \multirow{2}{*}{$\begin{array}{l}\mathrm{pH} \\
\text { valu } \\
\mathrm{e}\end{array}$} & \multirow[t]{2}{*}{$\begin{array}{l}\text { Conditio } \\
\mathrm{n}\end{array}$} & \multicolumn{2}{|c|}{$\begin{array}{l}\text { Calculation formulas } \mathrm{pH} \\
\text { equivalent }\end{array}$} \\
\hline & & & $\begin{array}{l}\text { Solution } \\
\mathrm{Na} 2 \mathrm{CO} 3+\mathrm{NaOH} \\
+\mathrm{CaCl} 2\end{array}$ & $\mathrm{pH}$ \\
\hline $\begin{array}{l}1 . \\
\text { Hydro- } \\
\text { carbona } \\
\text { te }\end{array}$ & $3-5$ & $\begin{array}{l}{[\mathrm{HCO} 3-]} \\
=[\mathrm{H}+]\end{array}$ & $\begin{array}{l}0.5(\mathrm{pK} 1- \\
-\lg \mathrm{C}(\mathrm{CO} 2)\end{array}$ & 4.0 \\
\hline $\begin{array}{l}2 . \\
\text { Calciu } \\
\text { m } \\
\text { carbona } \\
\text { te }\end{array}$ & $\begin{array}{l}6.8- \\
8\end{array}$ & $\begin{array}{l}{[\mathrm{CaCO} 3]} \\
= \\
{[\mathrm{CO} 2]}\end{array}$ & $\begin{array}{l}0.5(\mathrm{pK} 1+\mathrm{pK} 2- \\
\operatorname{lgCCa} 2+-\lg \mathrm{C} \\
(\mathrm{CO} 2)-0.5 \mathrm{p} \Pi \mathrm{P})\end{array}$ & 7.6 \\
\hline $\begin{array}{l}\text { 3.Carbo } \\
\text { nate }\end{array}$ & $\begin{array}{l}8- \\
8.2\end{array}$ & $\begin{array}{l}{[\mathrm{CO} 32-} \\
]=[\mathrm{CO} 2]\end{array}$ & $0.5(\mathrm{pK} 1+\mathrm{pK} 2)$ & 8.3 \\
\hline $\begin{array}{l}4 . \\
\text { Hydrox } \\
\text { yl }\end{array}$ & $\begin{array}{l}10.5 \\
-11.5\end{array}$ & $\begin{array}{l}{[\mathrm{OH}-} \\
]=[\mathrm{HCO} 3 \\
-]\end{array}$ & $\begin{array}{l}0.5(\mathrm{pK} 2+14+\lg \\
\mathrm{C}(\mathrm{CO} 2))\end{array}$ & 11 \\
\hline
\end{tabular}

The $\mathrm{pH}$ spectra, as follows from the data presented, indicate the presence (or absence) of phase-unstable solutions, and allow obtaining accurate data on the titrant consumption at the equivalence points, usually obtained by the volumetric method with phenolphthalein and methyl orange indicators.

Figure 3 shows a comparison of the solutions $\mathrm{pH}$ spectra in the absence of the "ACTIFOS" phosphonate. Figures 4 and 5 show a comparison of the solutions $\mathrm{pH}$ spectra in the presence of increasing volumes of a phosphonate solution with a concentration of $\mathrm{T}=3 \cdot 10$ $5 \mathrm{~g} / \mathrm{cm} 3-5$ and $15 \mathrm{ml}$ of this solution. These figures clearly indicate the inhibitory effect of phosphonate under the studied conditions.

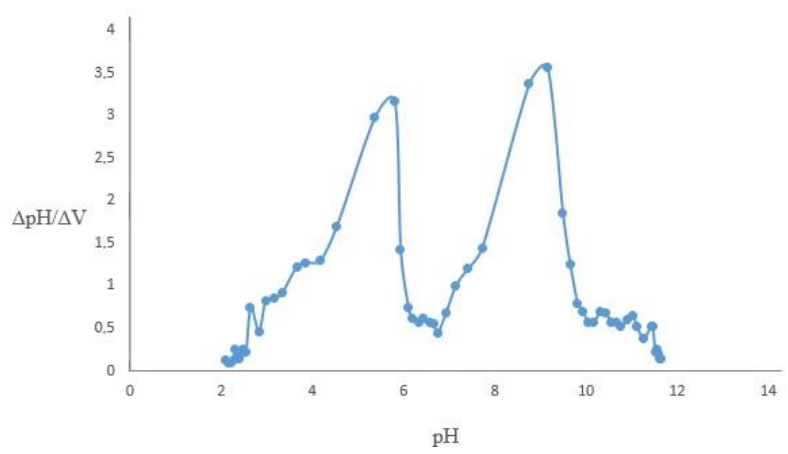

Fig. 3. $\mathrm{pH}$ spectrum in the absence of the «Aktifos» inhibitor. 


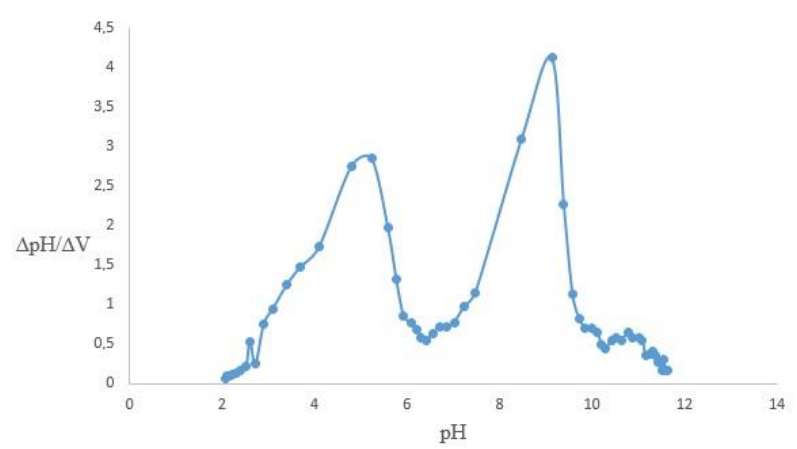

Fig. 4. pH spectrum in the presence of «Aktifos» with a concentration of $\mathrm{T}=3 \cdot 10^{-5} \mathrm{~g} / \mathrm{cm}^{3}-5 \mathrm{ml}$.

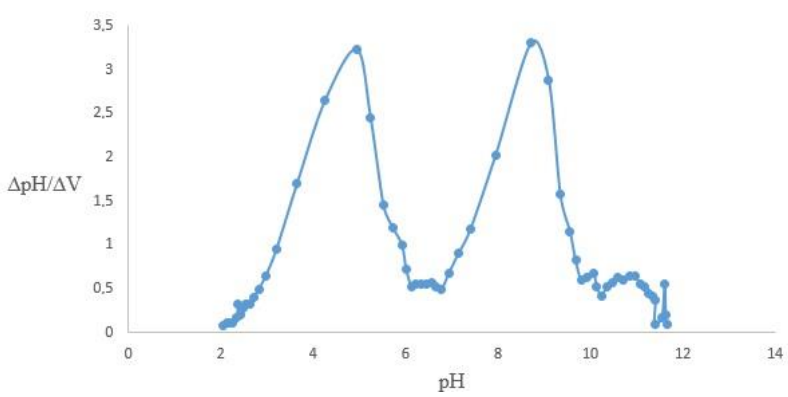

Fig. 5. pH spectrum in the presence of the «Aktifos» inhibitor with a concentration of $\mathrm{T}=3 \cdot 10^{-5} \mathrm{~g} / \mathrm{cm}^{3}-5 \mathrm{ml}$.

The data obtained and the analysis of $\mathrm{pH}$ spectra for phase-unstable solutions in the absence and presence of phosphonates suggest that the $\mathrm{pH}$-metric method is faster and less laborious for the experimental assessment of the phosphonates inhibitory action effectiveness, in contrast to the methods described in the literature: by changing the water hardness and crystal-optical method [3].

According to the source [4], the occurrence and growth of the sediment nuclei (this is the minimum amount of a new phase capable of independent existence) to a critical size ensures its stability. If crystals are up to $10-8 \mathrm{~m}$ in size, these are colloidal systems, i.e. it is a supersaturated but reasonably stable solution. At this stage, the sediment nuclei can spontaneously dissolve, their further growth or crystallization can occur. Further crystal growth will lead to the possible formation of a precipitate in solution.

When analyzing the literature on the stages of precipitation formation and on the mechanism of the phosphonates inhibitory effect, we noticed that the phosphonates inhibitory effect is explained by the increased hydrophilization of the crystal surface. [4] This information stimulated our research on the nature of the impact the nature of the alkali metal cation $\left(\mathrm{Li}^{+}-\mathrm{Na}^{+}-\mathrm{K}^{+}\right)$on the $\mathrm{pH}$-spectra in the system under consideration, since different hydration capacity is known for these cations [5].

Figure 6, 7 and 8 show the $\mathrm{pH}$ spectra of solutions with the components same concentration, but differing in the nature of the alkaline cation

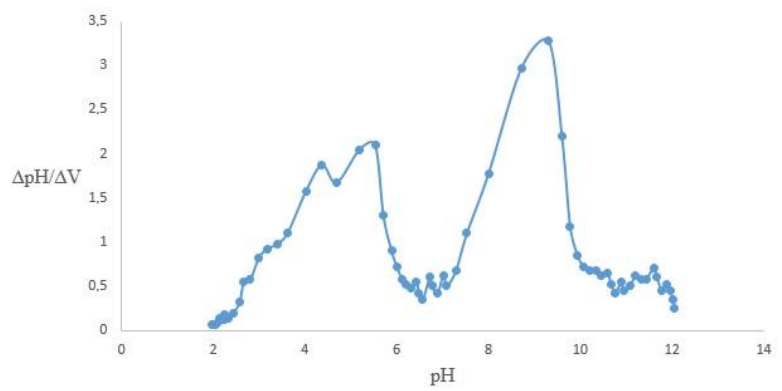

Fig. 6. $\mathrm{pH}$ spectrum for $\mathrm{CaCl}_{2}-\mathrm{K}_{2} \mathrm{CO}_{3}-\mathrm{KOH}$ solution.

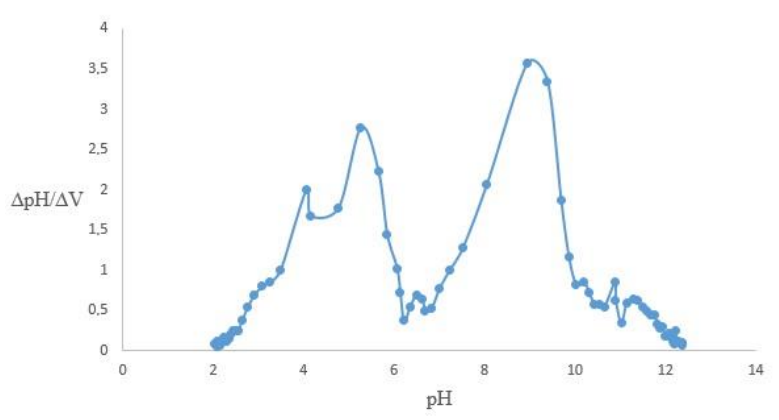

Fig. 7. $\mathrm{pH}$ spectrum for $\mathrm{CaCl}_{2}-\mathrm{Na} 2 \mathrm{CO}_{3}-\mathrm{NaOH}$ solution.

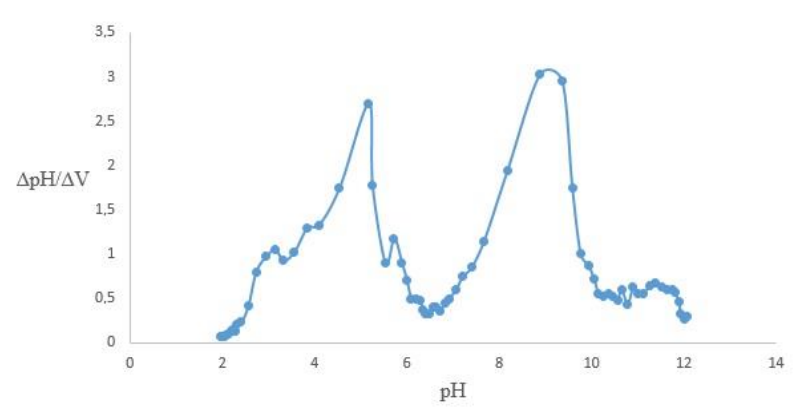

Fig. 8. $\mathrm{pH}$ spectrum for $\mathrm{CaCl} 2-\mathrm{LI} 2 \mathrm{CO} 3-\mathrm{LIOH}$ solution.

\section{Conclusions}

Comparison of the spectra shows that the nature of the alkali metal can affect the state of phase unstable solutions and suggests that the nature of the alkali metal can affect the phase unstable solutions formation, which requires further research.

The data obtained and the analysis of $\mathrm{pH}$ spectra for phase-unstable solutions in the absence and presence of phosphonates suggest that the $\mathrm{pH}$-metric method is faster and less laborious for the experimental assessment of the phosphonates inhibitory action effectiveness, in contrast to the methods described in the literature: by changing the water hardness and crystal-optical method.

\section{References}

1. R.I. Razakova, B.A. Gilfanov, Studies of the influence of the concentration and nature of components on carbon dioxide equilibrium in the $\mathrm{CaCl} 2-\mathrm{Na} 2 \mathrm{CO} 3-\mathrm{NaOH}-\mathrm{H} 2 \mathrm{O}$ system by potentiometric titration, Materials of the $\mathrm{X}$ 
International Youth Scientific Conference "Tinchurin Readings", ed. ed. Rector of KSPEU E.Yu. Abdullazyanov, in 3 volumes, 2, Kazan, Kazan. state energ. un-t, 91 (2015)

2. A.G. Filimonov, A.A. Chichirov, L.I. Gainutdinova, N.D. Chichirova, Methods for analyzing phase-unstable media in water heat carriers of TPPs and heat supply systems, Problems of energy, 5-6, 11-16 (2012)

3. A.G. Filimonov, A.A. Chichirov, L.I. Gainutdinova, N.D. Chichirova, Potentiometric and $\mathrm{pH}-$ spectroscopic analysis of weakly alkaline metastable carbonate solutions, Energy saving and water treatment, 1, 11-14 (2012)

4. A.L. Khoroshilov, I.V. Semenova, S.V. Simonova, Regularities of calcite formation during alkaline water treatment, Energosberezhenie i vodopodgotovka, 3, 20-22 (2004)

5. T.V. Tsukanova, I.V. Molgacheva, An inhibitor for corrective water treatment of heat supply systems - from laboratory tests to industrial implementation, Heat supply news, 2, 49-55 (2015)

6. O.Ya. Samoilov, Physical chemistry of solutions (Moscow: Nauka, 131, 1972)

7. A.G. Filimonov, A.A. Chichirov, L.I. Gainutdinova, N.D. Chichirova, Methods of analysis of phase-unstable media in water coolants of thermal power plants and heat supply systems, Problems of energy, 11-15 (2012)

8. Yu.V. Balaban-Irmenin, Regularities of scale formation in water-heating equipment of heat supply systems (review), Energy saving and water treatment, 3, 10-16 (2004)

9. B.N. Driker, S.A. Tarasova, A.N. Obozhin, A.G. Tarantaev, N.V. Tsirulnikova, Complex inhibitor of salt content, corrosion and biofouling based on organic phosphonates, Water treatment and water treatment equipment, 1 (63), 4-6 (2010)

10. Yu.V. Balaban-Irmenin, On the need to take into account the influence of natural organic matter when choosing a mode for the use of antiscale in energy, Energy saving and water treatment, 1, 712 (2010)

11. K.N. Brusov, On dispersed carbonate-calcium scale during inhibition by phosphonates, Energy saving and water treatment, 1, 31-33 (2011)

12. A.A. Chichirov, N.D. Chichirova, M.A. Volkov, S.M. Vlasov, I.A. Zakirov, Complex reagent water treatment of the technical water supply system with cooling towers at TPPs, Transactions of Academenergo, 1, 90-100 (2012)

13. S.A. Kraevoy, N.A. Koltovoy, The structure and properties of water (M., 8-18, 2014)

14. A.A. Chichirov, A.A. Filimionova, B.A. Gilfanov, A.A. Gafiatullina, N.D. Chichirova. Potentiometric analysis of metastable carbonate water coolants of thermal power plants and heat supply systems, IOP Conf. Ser .: Earth Environ., Sci., 288, 012004 (2019)

15. A.A. Chichirov, N.D. Chichirova, M.A. Volkov, S.M. Vlasov, I.A. Zakirov, Complex reagent water treatment of the technical water supply system with cooling towers at TPPs, Transactions of Academenergo, 1, 90-100 (2012) 